\title{
Utilização do Sistema Sonar (bandinha digital) na avaliação auditiva comportamental de lactentes $* * * *$
}

\author{
Sonar System- digital sounds of instruments for behavior hearing \\ tests with infants
}

\author{
Helenice Yemi Nakamura* \\ María Cecília Marconi Pinheiro Lima** \\ Vanda Maria Gimenes Gonçalves***
}

*Fonoaudióloga. Doutoranda em Ciências Médicas na Área de Neurologia da Faculdade de Ciências Médicas da Universidade Estadual de Campinas. Docente dos Cursos de Fonoaudiologia da Universidade Estadual de Campinas e Universidade Metodista de Piracicaba. Endereço para correspondência: R. Dr. Ruberlei Boaretto da Silva, 366 - Campinas - SP - CEP 13083-705

(nakamur@fcm.unicamp.br).

**Fonoaudióloga. Doutora em Ciências Médicas na Área de Neurologia da Faculdade de Ciências Médicas da Universidade Estadual de Campinas. Docente dos Cursos de Fonoaudiologia do Centro de Estudos e Pesquisas em Reabilitação Professor Doutor Gabriel Porto - Faculdade de Ciências Médicas e da Universidade Estadual de Campinas.

$* * *$ Neurologista. Livre-Docente do Departamento de Neurologia da Faculdade de Ciências Médicas da Universidade Estadual de Campinas. Professora Titular do Departamento d Neurologia da Faculdade de Ciências Médicas da Universidade Estadual de Campinas.

****Trabalho Realizado no Centro de Pesquisa e Reabilitação Professor Doutor Gabriel Porto da Universidade Estadual de Campinas.

\section{Artigo de Pesquisa}

Artigo Submetido a Avaliação por Pares

Conflito de Interesse: não

Recebido em 02.08.2004

Revisado em 10.10.2004; 28.03.2005; 17.05.2005; 30.05.2005; 10.10.2005; 12.01.2006; 13.03.2006

Aceito para Publicação em 14.03.2006

\begin{abstract}
Background: the use of musical instruments, in the clinical practice, for the behavioral assessment of hearing has a limited possibility to control loudness, and does not restrict the test situation to a determined frequency. A new method of testing infants is through the Sonar System. This program can be used for the behavioral hearing assessment of infants, with the possibility of choosing the frequency range and loudness in which the test will be carried out. The Sonar System is different from other behavioral assessment methods once it offers instruments with standardized sounds and is limited to certain frequency ranges; all controlled by the examiner. With this method, one can offer more precise assessments and researches with better methodological control, once the presented sound will not suffer interferences of the examiner. Aim: to use the Sonar System - digital band - to follow up the development of hearing in infants, born at term, from one to six months of age. Method: an average of 30 infants was monthly evaluated. For the assessment the following recordings of instruments were presented: clapper, ganzá, coco and drum. These recordings were respectively set at the frequencies of 3000, 1500, 700 and 500 $\mathrm{Hz}$. All infants went through evoked otoacoustic emissions screening. Results: Statistical analysis revealed significant responses in all of the tested frequencies. Results indicated statistically significant differences in all of the tested frequencies for the second trimester, but not for the first one. Conclusion: the use of the Sonar System (digital band) is recommended for the behavioral hearing assessment of this age group. Since this is a new technique to assess behavioral hearing, the use of the Sonar System should be expanded to other populations and in other social contexts in order to allow and facilitate the assessment, diagnosis and intervention of infants and small children.
\end{abstract}

Key Words: Hearing; Hearing Tests; Deafness; Behavioral Audiometry.

\section{Resumo}

Tema: a tradicional utilização de instrumentos musicais, para avaliação do comportamento auditivo oferece pouca possibilidade no controle de intensidade, além da impossibilidade de limitar a freqüência teste, na prática clínica. Um novo método de avaliação infantil surge com o Sistema Sonar, que pode ser utilizado na avaliação auditiva comportamental de lactente, com a possibilidade de escolha da faixa de freqüência e intensidade em que o teste será realizado. A utilização do Sistema Sonar diferencia-se de outros métodos de avaliação comportamental, pelo uso de um instrumento com sons padronizados e limitados em faixas de freqüências, controlados pelo avaliador. Com este método, podem-se propor avaliações mais confiáveis e pesquisas com maior rigor científico, pois a qualidade do som não sofrerá interferências do examinador e alteração de suas características. Objetivo: utilizar o Sistema Sonar (bandinha digital) para acompanhar o desenvolvimento da função auditiva de lactentes nascidos a termo, de um a seis meses de idade. Método: Foram avaliados, mensalmente, uma média de 30 lactentes. Para avaliação, foram apresentados a gravação dos instrumentos chocalho, ganzá, coco e tambor centralizados nas freqüências de $3000,1500,700$ e $500 \mathrm{~Hz}$, respectivamente. Todos passaram na triagem das emissões otoacústicas evocadas. Resultados: $\mathrm{Na}$ análise dos dados observa-se a presença de respostas de estatisticamente significantes nas freqüências testadas. Os resultados apresentaram diferença e statisticamente significativa, em todas as freqüências, no segundo trimestre, o que não aconteceu no primeiro trimestre. Conclusão: a utilização do Sistema Sonar (bandinha digital) é recomendada para avaliar esta faixa etária. Por se tratar de uma nova técnica de avaliação auditiva comportamental a utilização do Sonar deve se expandir com outras populações e em outros contextos sociais, e dessa maneira, possibilitar a avaliação de lactentes e de crianças pequenas de forma a facilitar o diagnóstico e a intervenção. Palavras-Chave: Audição; Testes Auditivos; Surdez; Comportamento Auditivo. 


\section{Introduction}

A new method of infant evaluation, the Sonar System - little digital band originated from the initiative of two phonoaudiologists and an electrical engineer (Lima et al., 2001). The instrument was elaborated to complement and update the infant hearing behavior and in any way, objectify what it is observed when evaluates children and options by utilizing the musical instruments (Nakamura, 2005).

When new technologies are absorbed in services offered to the neonate, with the creation of programs of neonatal triage, there is an increasing demand of infants with lower age who will need an accompaniment. The Sonar System little digital band may be incorporated in the battery of evaluations of this population, offering a better knowledge of the children hearing conditions, and then orientate and/or habilitate them.

Gravel and Hood (2001) suggested the inclusion of new procedures in the battery of tests fulfilled in very small infants and pointed as requirement the efficiency of the test utilized and the cost adequacy.

The use of the System Sonar (digital little band) with infants is an efficient method and of low cost and that knowledge of the auditory conditions of the child can be incorporated in the battery of the evaluations of this population offering better, and in this way to guide early identification and appropriate intervention for hearing loss.

The knowledge of characteristics (frequency and intensity) of the sonorous stimuli utilized in the hearing evaluation and the development of the hearing function are primordial to understand and relate the reactions of the infant face the stimuli presentation.

The subjectivity of the evaluation of infants shouldn't be associated with the presented stimuli. The approach to knowledge of the sonorous stimuli used in the hearing behavior evaluation may lead to little clarified interpretations about the function questioned.

In the behavioral evaluation of hearing by means of instrumental sound, it is very important to distinguish the frequency zones that are being stimulated or not. A lot of studies in the area point to the need of knowing at least the spectral characteristics of instrumental sounds used in behavioral evaluation of hearing (Northern and Downs, 2005; Chirelli et al., 2002; Azevedo et. al, 1995).

Even though the instrumental sounds present low cost, are easy to be applied and handled by expert appraisers, it is difficult to reproduce them always at the same way. When the phonoaudiologist handle them, he should maintain the same muscle strength, in order to not alter the intensity of sound, and the same distance between the sound and the child's ear.

Chirelli et al. (2002) performed a study with the objective of discussing the information provided by 16 musical instruments regarding the frequency and intensity spectrum of sounds generated. Concerning the first characteristic, each instrument has its spectrum and peaks of higher power concentrated in certain frequencies. In the evaluation of an instrument sound quality only the distribution of that power in function of the frequency is used. Furthermore, the band width used in the filters, usually of $3 \mathrm{~dB}$, great variability (between $15.6 \%$ and $76.8 \%$ ) of power. The authors showed that instrumental sounds with concentrations of characteristic power spectrum often present important components out of the dominant region of the power spectrum.

The utilization of the designation "rude sounds" shows that the researchers are aware that there is predominance of the sound spectral composition for this or that zone, although they do not assure that the answer is effectively from the dominant zone or other frequency zone in which eventually the child presents a more adequate answer.

In addition to frequency limitations, it is verified in the daily practice that the utilization of instruments offers a little possibility in the intensity control. Normally, they are defined as instruments with strong sounds (high density), medium (medium intensity) or weak (low intensity). It is virtually impossible that the examiner maintains exactly the same rhythm and intensity in each sound presentation.

Considering the difficulties to maintain the related acoustic characteristics, the utilization of an evaluation with complex sounds limited to bands of frequency and normalized in amplitude is justified. The sounds of the Sonar System - little digital band (Lima et al., 2001) were obtained from natural sources normalized by computer and recorded in Compact Disk. 
The obtainment of filtered and normalized complex sounds was performed in several parts: sign record, segment selection, sign selection, filter selection and projects, straining, square cutting, normalization, sign admeasurement and acceptance. The sign processing was fulfilled in digital computer, utilizing a quality standard CD.

Eight among 16 instruments initially recorded were selected. The utilized instruments, the central frequencies, as well as the cadency in pulses per second (pps) are presented on Table 1.

TABLE 1. Instruments, central frequencies and percussion cadencies.

\begin{tabular}{c|c|c}
\hline Instrument & Frequency $(\mathrm{Hz})$ & Cadency $(\mathrm{pps})$ \\
\hline tambour & 500 & 3,0 \\
coco & 700 & 3,5 \\
afochê & 1.000 & 4,0 \\
ganzá & 1.500 & 5,0 \\
castanets & 2.000 & 6,0 \\
clapper & 3.000 & 9,0 \\
reco-reco & 4.000 & 5,0 \\
caxixi & 8.000 & 9,0 \\
\hline
\end{tabular}

The use of the Sonar System - little digiral band in the behavioral evaluation of hearing differenciates from other behavioral evaluation methods, because by utilizing an instrument with standardazed and limited sounds in frequency zones, the appraiser knows previously the intensity of sound that is offering and in which frequency the sound is. Through this method more reliable evaluations and more scientifically rigorous researches can be proposed, considering that the sound quality will not suffer interferences of the appraiser and alteration of its characteristics.

This work is included in the Detection Program of Neuromotor and Sensorial Alterations in Term Infants with Adequate Weight and Low Birth Weight, which began in 2000 , developed by the Interdisciplinary Group for Infant Development Evaluation (GIADI), registered in the directory of the National Research Council (CNPq). Currently, The GIADI is constituted by nine researchers from the social assistance, physiotherapy, phonoaudiology, infant neurology, pediatrics, psychology and ocuppational therapy areas.

The interdisciplinary team approach, in which professionals from different disciplines bring their knowledge to compound strategies of evaluation, allows works of relevance on the infant development approach (Gagliardo, 2003 a; Lima, 1997).

The adopted procedure structure was created according to the infant development and it constitutes by contributions/co-actions of other members of the GIADI.

This way, the objective of this work was to observe the hearing function development in term infants by utilizing the Sonar System - little digital band.

\section{Method}

It was utilized an analytical and prospective study developed into the Laboratory of Infant Development Study I (LEDI-I) at the Center for Studies and Research in Rehabilitation "Prof. Dr. Gabriel Porto" (CEPRE) in collaboration with the Departments of Pediatrics and Neurology of the Medical Sciences School, University of Campinas (FCM - Unicamp). The evaluation rooms are acoustically treated, obtained through resource from the State of São Paulo Research Foundation (Fapesp) (Document n. 96/11 422, infrastructure project), with environmental noise level controlled and inferior to $45 \mathrm{~dB}$ SPL, according to recommendation for hearing evaluation in free field. The present work was approved by the Ethics Research Committee of the FCM - Unicamp, under the n. 17/2000.

The infants were selected on the first 24 hours of life, at the Neonatology Service of the Center for Integral Assistance to Women's Health (CaismUnicamp), complying with the following inclusion criteria: term newborn with weight higher to $2000 \mathrm{~g}$, not gemellary and in state of perfect health. Neonates with malformations, congenital infections or genetic syndromes diagnosed at birth, those who were hospitalized at the Intensive Therapy Unit and those who presented some indicator of deafness risk were excluded (JCIH, 2000; 1994; Azevedo, 1996). After the selection of subjects, the first evaluation date was scheduled, approximately on the subsequent seven days to the birthday, monthly accompanied during the first semester of life.

From May 2000 to September 2002, at the conjoint lodge of the Caism- Unicamp, fifty-five families were invited by the social service in order to participate in the Detection Program of Neuromotor and Sensorial Alterations in Term Infants with Adequate Weight and Low Birth 
Weight. Among them, 42 (76\%) families attended at least to one behavioral evaluation of hearing, in which parents or a legal responsible person signed the Free and Clarified Consent Term. This project was approved by the Ethics Research Committee of the FCM.

On the monthly visits all of infants were checked by the external acoustic meatus (EAM) meatoscopy, which was fulfilled previously to the hearing evaluation, aiming to discard possible alterations that could forbid or compromise the examination results.

The triage was made with evoked otoacoustic emissions (ILO Ecocheck).

Sonorous instrumental sounds that are part of the Sonar System - little digital band were presented (Table 2).

The sonorous stimuli was presented to $20 \mathrm{~cm}$ from the auricular pavilion alternately in the right and left ears, using a compact disc player (AIWA XP-3) at the stated intensity of $85 \mathrm{~dB}$ SPL for infants from one to four months of age. From the fifth month the stated intensity was of $75 \mathrm{~dB}$ SPL.

In order to verify the possibility of using the same exit for the two acoustic boxes, it was utilized the type 2232, Brüel \& Kjauer decibelimeter, on the fast A scale, with exits in $\mathrm{dB}$ SPL at the volume presented in the compact disk (Table 3 ).

The stimuli were presented in acoustic boxes for computer (Multi-Media amplifier speaker system, Upson), positioned on the infant head laterals, in dorsal decubitus, up to the third month. From the fourth month, the acoustic boxes were suspended in a support specially projected and built for the work (Figure 1).

The infants were in awake alert state (state IV) (Brazelton, 1984) i.e. with well alive eye, receptive to external stimuli, moderate motor activity.

The infants between one and three months were positioned in dorsal decubitus, with symmetric posture i.e. head supported in a wedge (7cm height, $35 \mathrm{~cm}$ width and $17 \mathrm{~cm}$ length) with elevations of 15 degrees for they could have cervical support and head spontaneous moving without limitation of movements, named position one (P1), according to the Figure 2.

From the fourth month the infants were evaluated seated on their mother's lap, held by the hip, named position two (P2), according to the Figure 3.
TABLE 2. Central frequency of instruments utilized in the proposed procedure.

\begin{tabular}{cc}
\hline Freqüência $(\mathrm{Hz})$ & Instrumento \\
500 & tambor \\
700 & coco \\
1.500 & ganzá \\
3.000 & chocalho \\
\hline
\end{tabular}

TABLE 3. Measurements of volume in SPL (sound pressure level).

\begin{tabular}{c|cc}
\hline \multirow{2}{*}{ Volume } & \multicolumn{2}{|c}{ Exit Intensity (SPL) } \\
\cline { 2 - 3 } & Measurement & Approximation \\
\hline 10 & 89,0 & 90 \\
9 & 88 & 90 \\
8 & 86,6 & 85 \\
7 & 84,4 & 85 \\
6 & 80,2 & 80 \\
5 & 76,8 & 75 \\
4 & 73,5 & 75 \\
3 & 70,0 & 70 \\
2 & 60,0 & 60 \\
1 & 50,0 & 50 \\
\hline
\end{tabular}

Distance of $1 \mathrm{~m}$ from the microphone to $1 \mathrm{~m}$ of height from the floor

The verification of the same sound intensity in the acoustic boxes before the use of the equipment for hearing evaluation is recommended.

FIGURE 1. Sonar System graph (Nakamura, 2005).
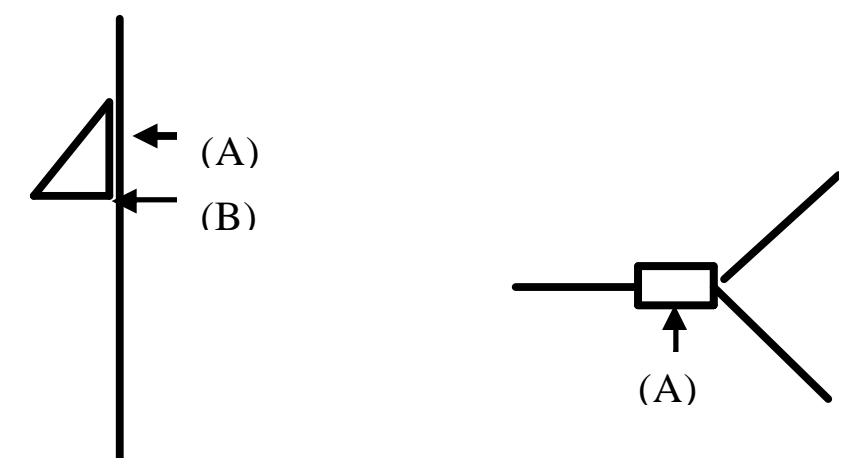

(C)

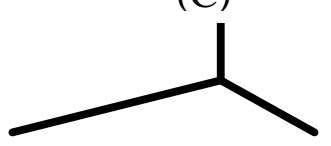

A: sound box support; B: hinge to fix the support (possibilitates the modification of height); C: metallic tube. 
FIGURE 2. Infant in the P1 position.

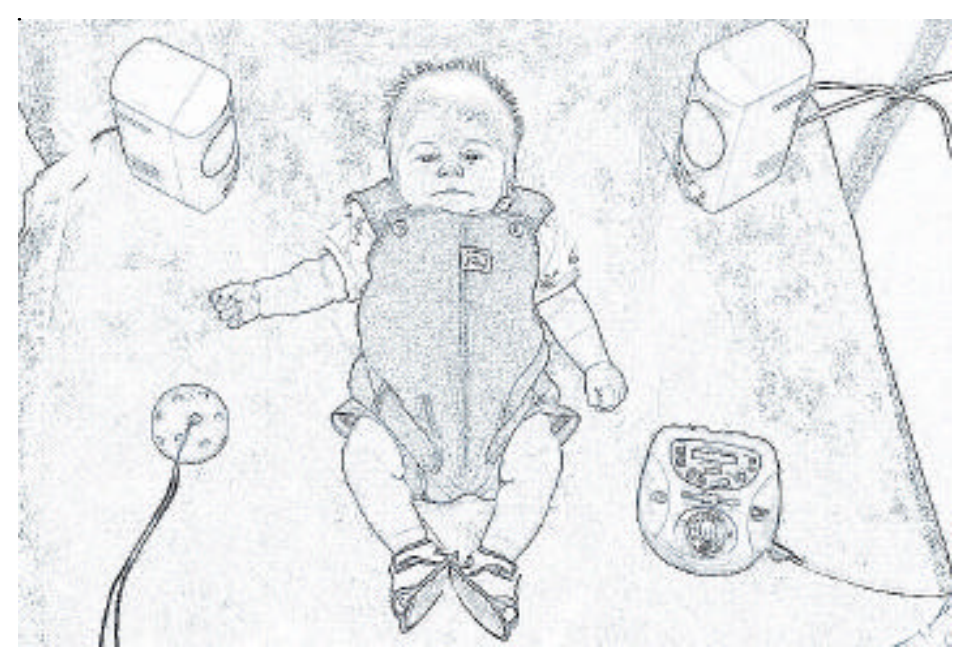

FIGURE 3. Infant in the position P2.

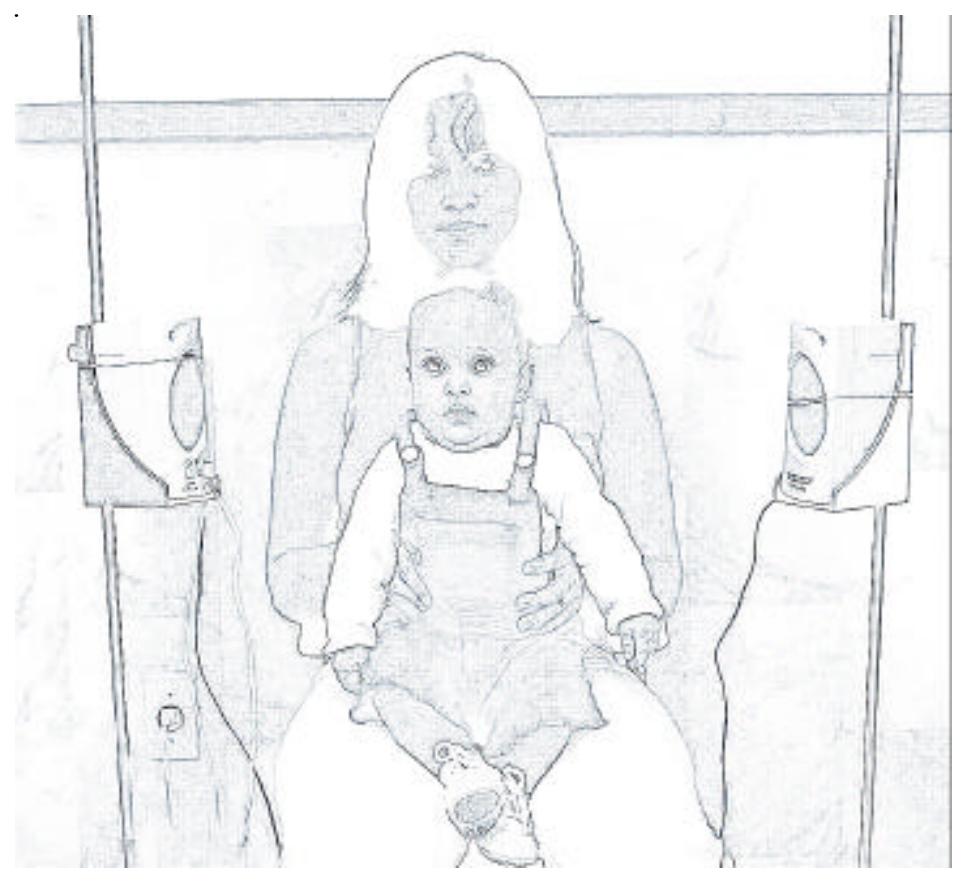

Stimuli up to 20 seconds of duration were presented for infants up to three months and stimuli up to 10 seconds of duration were presented for infants from three months. The stimulus presentation distance was $20 \mathrm{~cm}$ from the infant auricular pavilion (Ruggieri-Marone et al., 2002; Costa, 2003).

We considered response to the Sonar System little digital band the first behavior modification observed after the stimulus presentation up to two seconds after the presentation. Two examiners at least, who should be in accordance with the answer observed, were present in all of evaluations.

As in searched literature the answers of attention response had not contemplated the findings gotten after the stimulation with the System Sonar, developed a classification that enclose observations divided in global corporal movements, facial movements, vocalization and weep (Nakamura et al., 2002).

Attention response (AR) classified as

- global corporal movements (increase or diminution of movements, scare, dance);

. facial movements (pucker of forehead; goggle the eyes - open palpebral fissure; elevate eyebrow; suction beginning or stop, look in the direction of the examiner);

. vocalization and weep (vocalization beginning or stop, weep beginning or stop);

\section{Head-turning response (HT)}

. lateral moving of the head after the presentation of the sonorous stimulus on the first three months. Sonorous source.

Search response (SR)

. search for the source direction; look around without correctly locating it.

Location response (LOC):

.turn back the head to the sonorous source. 
All of evaluations were recorded with a Panasonic video camera (Omni Movie VHS HQ AFX 6 CCD).

The percentage calculation was utilized in order to do the descriptive analysis of the results month per month. The Cochran's exact test was utilized to compare coupled proportions for longitudinal analysis of infants who attended all of quarterly evaluations. The significance level adopted was $5 \%$. The packet utilized for the statistical procedures was the "System for Windows" (Statistical Analysis System - SAS), version 8.2.

\section{Results}

Twenty-two infants were evaluated on the first month, thirteen (59\%) from female sex and $9(41 \%)$ from male sex. All of infants passed in the triage with evoked otoacoustic emissions. The response distribution of the infants observed on the first month is presented on Table 4.

The most frequent response was the attention response (AR) in both ears. There was the appearance of the head-turning response (HT) with 11 occurrences. The response absence (RA) in the frequency of $700 \mathrm{~Hz}$ in the right ear was lesser than $5 \%$.

Thirty-one infants were evaluated on the second month, $22(71 \%)$ from female sex and $9(29 \%)$ from male sex. The response distribution observed on the second month is presented on Table 5 .

The most frequent response was attention response (AR) in both ears; the head-turning (HT) with 14 occurrences and response absence (RA) lesser than $5 \%$ in the frequency of $3000 \mathrm{~Hz}$.

Thirty-two infants were evaluated on the third month, $20(62.5 \%)$ from female sex and $12(37.5 \%)$ from male sex. The responses observed on the third month are presented on Table 6.

The most frequent response on the third month was the attention response (AR) in both ears, the head-turning (HT) with 26 occurrences and response absence (RA) lesser than $5 \%$ in the frequency of $3000 \mathrm{~Hz}$.

Thirty-four infants on the fourth month were evaluated, $22(65 \%)$ from female sex and $12(35 \%)$ from male sex. The response frequencies observed on the fourth month are presented on Table 7.

The most frequent response was the attention response (AR) with 200 occurrences in both ears. The location response (LOC) was observed from the fourth month with 42 occurrences, and sonorous source search (SS) with 19 occurrences. The response absence (RA) was lower than $10 \%$.

Thirty-two infants were evaluated on the fifth month, $21(66 \%)$ from female sex and $11(34 \%)$ from male sex. The response frequencies observed on the fifth month are presented on Table 8.

TABLE 4. Response distribution of infant on the first month.

\begin{tabular}{|c|c|c|c|c|c|c|c|c|c|}
\hline & & \multicolumn{8}{|c|}{ Frequiências (Hz) } \\
\hline \multirow[b]{2}{*}{ Respostas } & & \multicolumn{2}{|c|}{$3000 \mathrm{~Hz}$} & \multicolumn{2}{|c|}{$1500 \mathrm{~Hz}$} & \multicolumn{2}{|c|}{$700 \mathrm{~Hz}$} & \multicolumn{2}{|c|}{$500 \mathrm{~Hz}$} \\
\hline & & $\mathrm{RE}$ & $\mathrm{LE}$ & $\mathrm{RE}$ & $\mathrm{LE}$ & $\mathrm{RE}$ & LE & $\mathrm{RE}$ & LE \\
\hline \multirow[t]{2}{*}{$\mathrm{AR}$} & $\mathrm{N}$ & 21 & 21 & 20 & 20 & 20 & 22 & 19 & 21 \\
\hline & $\%$ & (95) & (95) & (91) & (91) & (91) & (100) & (86) & (95) \\
\hline \multirow[t]{2}{*}{ HT } & $\mathrm{N}$ & 01 & 01 & 02 & 02 & 01 & - & 03 & 01 \\
\hline & $\%$ & $(4,5)$ & $(4,5)$ & (9) & (9) & $(4,5)$ & & (14) & $(4,5)$ \\
\hline \multirow[t]{2}{*}{ RA } & $\mathrm{N}$ & - & - & - & - & 01 & - & - & - \\
\hline & $\%$ & & & & & $(4,5)$ & & & \\
\hline TOTAL & & 22 & 22 & 22 & 22 & 22 & 22 & 22 & 22 \\
\hline
\end{tabular}

$\mathrm{RE}=$ right ear; $\mathrm{LE}=$ left ear; $\mathrm{AR}=$ attention response $\mathrm{HT}=$ head-turning; $\mathrm{RA}=$ response absence. 
TABLE 5. Response distribution of infants on the second month.

\begin{tabular}{|c|c|c|c|c|c|c|c|c|c|}
\hline & & \multicolumn{8}{|c|}{ Frequiências (Hz) } \\
\hline & & \multicolumn{2}{|c|}{$3000 \mathrm{~Hz}$} & \multicolumn{2}{|c|}{$1500 \mathrm{~Hz}$} & \multicolumn{2}{|c|}{$700 \mathrm{~Hz}$} & \multicolumn{2}{|c|}{$500 \mathrm{~Hz}$} \\
\hline Responses & & $\mathrm{RE}$ & LE & $\mathrm{RE}$ & LE & $\mathrm{RE}$ & LE & $\mathrm{RE}$ & LE \\
\hline \multirow[t]{2}{*}{$\mathrm{AR}$} & $\mathrm{N}$ & 28 & 30 & 30 & 30 & 28 & 29 & 30 & 27 \\
\hline & $\%$ & $(90)$ & (97) & (97) & (97) & (90) & (94) & (97) & (87) \\
\hline \multirow[t]{2}{*}{ HT } & $\mathrm{N}$ & 02 & - & 01 & 01 & 03 & 02 & 01 & 04 \\
\hline & $\%$ & (7) & & (3) & (3) & (10) & (6) & (3) & (13) \\
\hline \multirow[t]{2}{*}{ RA } & $\mathrm{N}$ & 01 & 01 & - & - & - & - & - & - \\
\hline & $\%$ & (3) & (3) & & & & & & \\
\hline TOTAL & & 31 & 31 & 31 & 31 & 31 & 31 & 31 & 31 \\
\hline
\end{tabular}

$\mathrm{RE}=$ right ear; $\mathrm{LE}=$ left ear; $\mathrm{AR}=$ attention response; $\mathrm{HT}=$ head-turning; $\mathrm{RA}=$ response absence .

TABLE 6. Response distribution of infants on the third month.

\begin{tabular}{|c|c|c|c|c|c|c|c|c|c|}
\hline \multirow[b]{3}{*}{ Responses } & & \multicolumn{8}{|c|}{ Freqüências $(\mathrm{Hz})$} \\
\hline & & \multicolumn{2}{|c|}{$3000 \mathrm{~Hz}$} & \multicolumn{2}{|c|}{$1500 \mathrm{~Hz}$} & \multicolumn{2}{|c|}{$700 \mathrm{~Hz}$} & \multicolumn{2}{|c|}{$500 \mathrm{~Hz}$} \\
\hline & & $\mathrm{RE}$ & LE & $\mathrm{RE}$ & LE & $\mathrm{RE}$ & $\mathrm{LE}$ & $\mathrm{RE}$ & LE \\
\hline \multirow[t]{2}{*}{$\mathrm{AR}$} & $\mathrm{n}$ & 26 & 24 & 28 & 28 & 32 & 29 & 29 & 31 \\
\hline & $\%$ & (82) & (75) & (88) & $(88)$ & (100) & (91) & (91) & (97) \\
\hline \multirow[t]{2}{*}{ HT } & $\mathrm{n}$ & 05 & 07 & 04 & 04 & - & 02 & 03 & 01 \\
\hline & $\%$ & (16) & (22) & (12) & (12) & & (6) & (9) & (3) \\
\hline \multirow[t]{2}{*}{ RA } & $\mathrm{n}$ & 01 & 01 & - & - & - & 01 & - & - \\
\hline & $\%$ & (3) & (3) & & & & (3) & & \\
\hline TOTAL & & 32 & 32 & 32 & 32 & 32 & 32 & 32 & 32 \\
\hline
\end{tabular}

$\mathrm{RE}=$ right ear; $\mathrm{LE}=$ left ear; $\mathrm{AR}=$ attention response $\mathrm{HT}=$ head-turning; $\mathrm{RA}=$ response absence .

TABLE 7. Response distribution of infants on the fourth month.

\begin{tabular}{|c|c|c|c|c|c|c|c|c|c|}
\hline \multirow[b]{3}{*}{ Responses } & & \multicolumn{8}{|c|}{ Freqüências $(\mathrm{Hz})$} \\
\hline & & \multicolumn{2}{|c|}{$3000 \mathrm{~Hz}$} & \multicolumn{2}{|c|}{$1500 \mathrm{~Hz}$} & \multicolumn{2}{|c|}{$700 \mathrm{~Hz}$} & \multicolumn{2}{|c|}{$500 \mathrm{~Hz}$} \\
\hline & & $\mathrm{RE}$ & LE & $\mathrm{RE}$ & LE & $\mathrm{RE}$ & LE & $\mathrm{RE}$ & LE \\
\hline \multirow[t]{2}{*}{$\mathrm{AR}$} & $\mathrm{n}$ & 21 & 28 & 26 & 25 & 23 & 27 & 24 & 26 \\
\hline & $\%$ & (62) & (82) & (76) & (73) & (68) & (79) & (70) & (76) \\
\hline \multirow[t]{2}{*}{ SS } & $\mathrm{n}$ & 05 & 01 & 03 & 03 & 01 & 02 & 02 & 02 \\
\hline & $\%$ & (15) & (3) & (9) & (9) & (3) & (6) & (6) & (6) \\
\hline \multirow[t]{2}{*}{ LOC } & $\mathrm{n}$ & 07 & 03 & 05 & 05 & 07 & 04 & 06 & 05 \\
\hline & $\%$ & (20) & (9) & (15) & (15) & (20) & (12) & (18) & (15) \\
\hline \multirow[t]{2}{*}{ RA } & $\mathrm{n}$ & 01 & 02 & - & 01 & 03 & 01 & 02 & 01 \\
\hline & $\%$ & (3) & (6) & & (3) & (9) & (3) & (6) & (3) \\
\hline TOTAL & & 34 & 34 & 34 & 34 & 34 & 34 & 34 & 34 \\
\hline
\end{tabular}

$\mathrm{RE}=$ right ear; $\mathrm{LE}=$ left ear; $\mathrm{AR}=$ attention response; $\mathrm{HT}=$ head-turning; $\mathrm{RA}=$ response absence. 
TABLE 8. Response distribution of infants on the fifth month.

\begin{tabular}{|c|c|c|c|c|c|c|c|c|c|}
\hline \multirow[b]{3}{*}{ Responses } & & \multicolumn{8}{|c|}{ Freqüências (Hz) } \\
\hline & & \multicolumn{2}{|c|}{$3000 \mathrm{~Hz}$} & \multicolumn{2}{|c|}{$1500 \mathrm{~Hz}$} & \multicolumn{2}{|c|}{$700 \mathrm{~Hz}$} & \multicolumn{2}{|c|}{$500 \mathrm{~Hz}$} \\
\hline & & $\mathrm{RE}$ & LE & $\mathrm{RE}$ & LE & $\mathrm{RE}$ & LE & $\mathrm{RE}$ & LE \\
\hline \multirow[t]{2}{*}{$\mathrm{AR}$} & $\mathrm{n}$ & 10 & 10 & 12 & 11 & 17 & 15 & 13 & 13 \\
\hline & $\%$ & (31) & (31) & (37) & (34) & (53) & (47) & (41) & (41) \\
\hline \multirow[t]{2}{*}{ SS } & $\mathrm{n}$ & 02 & 05 & 06 & 02 & 03 & 01 & 01 & - \\
\hline & $\%$ & (6) & (16) & (19) & (6) & (9) & (3) & (3) & \\
\hline \multirow[t]{2}{*}{ LOC } & $\mathrm{n}$ & 19 & 15 & 13 & 19 & 10 & 15 & 16 & 17 \\
\hline & $\%$ & (59) & (47) & (41) & (59) & (31) & (47) & (50) & (53) \\
\hline \multirow[t]{2}{*}{ RA } & $\mathrm{n}$ & 01 & 02 & 01 & & 02 & 01 & 02 & 02 \\
\hline & $\%$ & (3) & (6) & (3) & & (6) & (3) & (6) & (6) \\
\hline TOTAL & & 32 & 32 & 32 & 32 & 32 & 32 & 32 & 32 \\
\hline
\end{tabular}

$\mathrm{RE}=$ right ear; $\mathrm{LE}=$ left ear; $\mathrm{AR}=$ attention response; $\mathrm{HT}=$ head-turning; $\mathrm{RA}=$ response absence.

The most frequent response was the location response (LOC) with 124 occurrences. The second most frequent was the attention response (AR) with 101 occurrences and the source search (SS) with 20 occurrences. The response absence was lower than $10 \%$.

Thirty-two infants were evaluated on the sixth month, $21(66 \%)$ from female sex and $11(34 \%)$ from male sex. The responses observed on the sixth month are presented on Table 9.

The most frequent response was the lateral location response (LOC) with 187 occurrences. The second most frequent was the attention response (RA) with 67 occurrences and source search (SS) with two occurrences in the right ear at 3000 and $1500 \mathrm{~Hz}$.

In the longitudinal evaluation of infants who attended all the evaluations on the first quarter, we found for the attention response at the frequency of $500 \mathrm{~Hz}$ a higher value of response on the second month. However, the difference was not statistically significant (Cochran's exact test).

On the second quarter analysis of responses of 21 infants who attended all the evaluations, we found a difference statistically significant in the attention response in all the frequencies (Table 10). On this quarter it was observed diminution of the attention response from the fourth to the fifth month. There was an increase of the location response despite the tested frequency.
TABLE 9. Response distribution of infants on the sixth month.

\begin{tabular}{|c|c|c|c|c|c|c|c|c|c|}
\hline & & \multicolumn{8}{|c|}{ Freqüências $(\mathrm{Hz})$} \\
\hline & & \multicolumn{2}{|c|}{$3000 \mathrm{~Hz}$} & \multicolumn{2}{|c|}{$1500 \mathrm{~Hz}$} & \multicolumn{2}{|c|}{$700 \mathrm{~Hz}$} & \multicolumn{2}{|c|}{$500 \mathrm{~Hz}$} \\
\hline \multicolumn{2}{|l|}{ Responses } & $\mathrm{RE}$ & LE & $\mathrm{RE}$ & LE & RE & LE & RE & LE \\
\hline \multirow[t]{2}{*}{$\mathrm{AR}$} & $\mathrm{n}$ & 11 & 09 & 05 & 09 & 09 & 07 & 07 & 10 \\
\hline & $\%$ & (34) & (28) & (16) & (28) & (28) & (22) & (22) & (31) \\
\hline \multirow[t]{2}{*}{ SS } & $\mathrm{n}$ & 01 & - & 01 & - & - & - & - & - \\
\hline & $\%$ & (3) & & (3) & & & & & \\
\hline \multirow[t]{2}{*}{ LOC } & $\mathrm{n}$ & 20 & 23 & 26 & 23 & 23 & 25 & 25 & 22 \\
\hline & $\%$ & (63) & (72) & (81) & (72) & (72) & (78) & (78) & (69) \\
\hline \multirow[t]{2}{*}{ RA } & $\mathrm{n}$ & - & - & - & - & - & - & - & - \\
\hline & $\%$ & & & & & & & & \\
\hline TOTAL & & 32 & 32 & 32 & 32 & 32 & 32 & 32 & 32 \\
\hline
\end{tabular}

$\mathrm{RE}=$ right ear; $\mathrm{LE}=$ left ear; $\mathrm{AR}=$ attention response; $\mathrm{HT}=$ head-turning; $\mathrm{RA}=$ response absence. 
TABLE 10. Value distribution of the attention response from four to six months Cochran's exact test.

\begin{tabular}{c|c|c}
\hline Freqüências & RE & LE \\
\hline & & \\
$3000 \mathrm{~Hz}$ & $\mathrm{P}=0,023$ & $\mathrm{P}<0,0001$ \\
$1500 \mathrm{~Hz}$ & $\mathrm{P}=0,004$ & $\mathrm{P}=0,005$ \\
$700 \mathrm{~Hz}$ & $\mathrm{P}=0,048$ & $\mathrm{P}=0,003$ \\
$500 \mathrm{~Hz}$ & $\mathrm{P}=0,004$ & $\mathrm{P}=0,010$ \\
\hline
\end{tabular}

Legenda: OD: right ear; OE: left ear.

\section{Discussion}

The presented responses (attention, headturning, source search, location) for the Sonar System - little digital band in the studied population are similar to those found by other authors (Azevedo, 1996, Nakamura, 1996; Costa et al., 2003; Northern and Downs, 2005).

By means of the result analysis we can observe the presence of responses between $91 \%$ and $100 \%$ in the tested frequencies. The method utilized was efficient by allowing observing, according to the age growing, the appearance of better elaborated responses after the stimulus presentation, as what was expected from the infant.

The attention response appeared since the first month, had an increase between the second and third months and tended to diminish from the fourth or fifth month. These results also were observed by Azevedo et al.(1995).

The head-turning appeared on the first three months, considering that it was most frequent on the second month; this response beginning on the first month was referred by Costa et al(2003). Azevedo et al. (1995) referred in the findings the head-turning observed between three and six months.

The lateral localization observed in all the frequencies from the fourth month coincided with the findings of Azevedo et al., (1995).

In the second trimester, with the application of the test of Cochran's, a statistically significant difference in the comparison of $4^{\circ}, 5^{\circ}$ and $6^{\circ}$ months in relation to the attention response, independent of the frequency and the ear $(\mathrm{P}<0,05)$.

For the localization response, also it occurred a statistically significant difference, independent of ear and frequency $(\mathrm{P}<0,05)$.
It can be observed that with the increase of the age it had the reduction of the attention response and an increase of the localization response from the fourth month, became from a less elaborated to a more elaborated response.

On the integrity of many systems it depends the acquisition and development of the verbal language, including the auditory system, the auditory processing, the cognitive development, the motor function (joint, praxis), the vision and the central processing of the vision (Lima et al., 2001b).

The exposition of the infants to the auditory stimulations during the first months of life will have relevance in the process of acquisition of the verbal language. In the area of audiologic assessment of newborn and infants it has a great concern in the use of techniques that congregate efficiency, rapidity and trustworthiness in the gotten data to know of the real auditory situation of so small patient.

The detention of auditory alterations and the intervention initiated until the six months of age guarantee to the child the development of the understanding and the expression of the language, as well as its social development, comparable to the one of the children listeners of the same age group (Yoshinaga-Itano et al., 1998; Johnson, 2002).

In this way, ours practical must be guided in the search of a fast and trustworthy ways of neonatal universal tests to guarantee the diagnosis in the first semester of life.

Lewis et al., (2002) had related that the implantation of services of newborn hearing screening (NHS) in Brazil was carried through in 16 states in a total of 75 hospitals. As data of the Group of Support Newborn Hearing Screening (GATANU), in 2005, the NHS was being carried through in 225 places in the country, in 21 states, with evaluations predominantly for otoacústicas emissions evoked by transient stimulation EOAET $(62 \%)$, in a high population of high and low risk (2004). In 2000, in a total of 32 states approximately 1000 hospitals in the United States had related auditory selection in $90 \%$ of the newborn (Harrison et al., 2003).

The Brazilian Committee of Auditory Loss in Infancy (CBPAI, 2000) recommended the implantation of the newborn hearing screening (NHS) with electrophysiological tests. In the impossibility of the accomplishment of electrophysiological tests, the possibility of the follow-up of the behavioral hearing test associate to the protocol of risk indicators for hearing loss, 
and the audiologic follow-up for children (CBPAI, 2000; Axe et al., 2000). In the state of the Colorado in 2000 it was published a guidelines with some recommended on the selection and audiologic follow-up, as well as the intervention, where it is suggested use of the behavioral hearing test in the audiologic diagnosis (CIHAC, 2000).

In the city of Campinas, on December 28, 2000 the law n.10759 was sanctioned, regulated on February 16, 2004, which disposes about the obligatoriness of the performance of examinations that detect the deafness or correlated alterations in maternities and hospitals of the city. The hearing evaluation techniques may be objective or subjective, according to the law text.

However, the performance of newborn hearing screening (TAN) or universal newborn hearing screening (TANU) should be observed as the initial part of a hearing evaluation process that will depend on other exams for the infant diagnose and accompaniment, carried through for the phonoaudiologists (Durante et al., 2004).

Concerning the utilization of subjective tests for newborn hearing screening, we considered that nowadays there are more adequate examinations that evaluate the hearing integrity in an objective way, such as the transient evoked otoacoustic emissions or by product of distortion and the hearing potential of encephalic trunk. However, behavioral evaluation of hearing must consist of the hearing accompaniment of infants and in the comparative of the results of the objective tests (Conne-Wesson et al., 2000; Walch, et al., 2000; Widen et al., 2003; Azevedo, 2004; Northern and Downs, 2005).

The behavioral evaluation of hearing highlights because of the easy performance and low cost; however, it requires experience and observation capability from the examiner (Mota et al, 2000; Walch et. al., 2000; GATANU, 2004), in addition to the knowledge about the process of infant development (Northern and Downs, 2005).
The hearing deficiency detention should be an observation pertinent to all the health professionals and concern a Public Health politics (Harrison et al., 2003), thinking about the improvement/ maintenance of the quality of life of our infant population (Nakamura et al, 2000; Taurozzi et al., 2003) and the promotion of the auditory health (Russo, 2000; MS, 2002).

The pursuing of the cases is the part most difficult of a program, but, without a doubt, the aspect most important for its success (Azevedo et. al, 1995; Azevedo, 1996), for the infants and its parents (Weber and Diefendorf, 2001; Kenna, 2003). The systematization of the accompaniment of infants contributes for the prevention, diagnosis and precocious intervention (MS, 2002; ASHA, 2004).

So or more important of the one than to opt to Newborn Hearing Screening or Universal Newborn Hearing Screening it is to guarantee to the infants a form of diagnostic front to the possibility of any auditory alteration (Murray, 2000; Nakamura, 2005).

Whatever the chosen examination, it should be adequate to the service that will utilize it, taking into account the cost of material, the need of specialized team to fulfill the evaluations. The professional experience together with simple, reliable and low cost tests is the key for the good performance in our field. (Nakamura, 1996).

The use of the System Sonar (digital little band) there was the control of variables related to the sonorous stimuli presentation on the percussion power, the maintenance of the sonorous source distance, the examiner interference (entry into the visual field, olfactory signs, etc). This control lack may interfere on the answer and compromise the results of the behavioral evaluation of hearing. Therefore, this instrument shows efficient for the evaluation of this age group infants. 


\section{Conclusion}

The method utilized was efficient by allowing observing, according to the age growing, the appearance of better elaborated responses after the sonorous stimulus presentation.

The attention response was observed since the first month, increased between the second and third months and tended to diminish from the fourth or fifth month.

The sonorous source search response started to be observed between the fourth and fifth months.

The head-turning towards the sonorous stimulus was observed on the first months, and was more frequent on the second month.
The sound lateral location was observed in all the frequencies since the fourth month.

It is important to highlight that responses to the sonorous stimuli were observed between $91 \%$ and $100 \%$ in the tested frequencies.

For if dealing with a new technique of behavior hearing tests, the use of the System Sonar must be become enlarged with other populations and in other social contexts, and in this way, make possible the evaluation of infants and small children to facilitate the diagnosis and the intervention (Nakamura, 2005).

\section{References}

AMERICAN SPEECH-LANGUAGE-HEARING ASSOCIATION. Guidelines for the audiologic assessment of children from birth to 5 years of age, 2004. 43p. Disponível em: 〈http://www.asha.org>. Acessoem: $19 \mathrm{ab} .2005$.

AZEVEDO, M. F. Programa de prevenção e identificação precoce dos distúrbios da audição. In: SCHOCHAT, E. Atualidades em Fonoaudiologia, v. II. São Paulo: Lovise, 1996. cap. 4, p. 75-105.

AZEVEDO, M. F. Triagem auditiva neonatal. In: FERREIRA, L. P.; BEFI-LOPES, D. M.; LIMONGI, S. C. O. (Org.). Tratado de Fonoaudiologia. São Paulo: Roca, 2004. cap. 47, p. 604-616.

AZEVEDO, M. F.; VILANOVA, L. C.; VIEIRA, R. M. Desenvolvimento Auditivo de crianças normais e de alto risco. São Paulo: Plexus, 1995. 222 p.

BRASIL. Ministério da Saúde. Portaria no 1060, de 5 de junho de 2002. Política Nacional de Saúde da Pessoa Portadora de Deficiência, Brasília.

BRAZELTON, T. B. The manual. In: BRAZELTON, T.B. Neonatal Behavioral Assesment Scale. 2. ed. Philadelphia: Spastics International medical Publications, 1984. p. 17-77.

CHIRELLI, A. M.; SOARES, E.; ARAÚJO, F. C. R. S. Análise espectral psicoacústica de instrumentos não calibrados: uma contribuição para a avaliação audiológica comportamental. In: PANHOCA, I.; LACERDA, C. F. B. Tempo de Fonoaudiologia, v. III. Taubaté: Cabral, 2002. cap. 13, p. 221-237.

COLORADO INFANT HEARING ADVISORY COMMITTEE. Guidelines for infant hearing screening, audiologic assessment, and intervention. Dec, 2000. Disponível em: 〈http://www.colorado.edu/slhs/mdnc>. Acesso em: 2 maio 2005.
COMITÊ BRASILEIRO SOBRE PERDAS AUDITIVAS NA INFÂNCIA. Recomendação 01/99. Jornal do Conselho Federal de Fonoaudiologia, v. 5, p. 3-7, 2000.

CONNE-WESSON, B.; VOHR, B. R.; FLETCHER, K. A.; NORTON, S. J.; GORGA, M. P. Identification of Neonatal Hearing Impairment: infants with hearing loss. Ear Hear., v. 21, n. 5, p. 488-507, 2000.

COSTA, S. A.; AZEVEDO, M. F.; FUKUDA, Y. Localização sonora em crianças: grau de movimentação da cabeça e latência da resposta. Pró-Fono R. Atual. Cient., v. 15, n. 2, p. 169-180, maio-ago. 2003.

DURANTE, A. S.; CARVALLO, R. M. M.; COSTA, M. T. Z.; CIANCIARULLO, M. A.; VOEGELS, R. L.; TAKAHASHI, G. M.; SOARES, A. V. N.; SPIR, E. G. Programa de Triagem Auditiva neonatal: modelo de Implementação. Arq. Otorrinolaringol., v. 8, n. 1, p. 56-62, 2004.

GAGLIARDO, H. G. R. G. Contribuições de Terapia Ocupacional para detecção de alterações visuais na Fonoaudiologia. Saúde R., v. 5, n. 9, p. 89-94, 2003.

GRUPODEAPOIO A TRIAGEMNEONATALUNIVERSAL - Gatanu. s.d. Disponível em: 〈http://www.gatanu.org.br>. Acesso em: 14 maio 2005.

GRAVEL, J. S.; HOOD, L. J. Avaliação audiológica infantil. In: MUSIEK, F. E.; RINTELMANN, W. F. Perspectivas atuais em avaliação auditiva. São Paulo: Manole, 2001. cap.10, p.301-322.

HARRISON, M.; ROUSH, J.; WALLACE, J. Trends in age of identification in infants with hearing loss. Ear Hear., v. 24, n. 1, p. 89-95, 2003.

JOINT COMMITTEE ON INFANT HEARING. 1994 Position Statement. s.d. Disponível em: \ttp://www.jcih.org/ posstatemts.htm. > Acesso em: 14 maio 2005. 
JOHNSON, K. C. Audiologic assessment of children with suspect hearing loss. Otolaringol. Clin. N. Am., v. 35, p. 711-732, 2002.

KENNA, M. A. Neonatal hearing screening. Pediatric. Clin. Am., v. 50, p. 301-313, 2003

LEWIS, D. R.; ALMEIDA, K.; CHAPCHAP, M. J. Newborn hearing screening in Brazil. In: INTERNATIONAL CONFERENCE ON NEWBORN HEARING SCREENING DIAGNOSIS AND INTERVENTION, 2. Book and abstracts, 2002. p. 37.

LIMA, M. C. M. P.; ARAÚJO, A. M. L.; ARAÚJO, F. C. R. S. Sistema Sonar: sons normalizados para a avaliação audiológica. Carapicuíba: Pró-fono, 2001. 78 p.

LIMA, M. C. M. P.; GAGLiARDO, H. G. R. G.; GONÇALVES, V. M. G. Desenvolvimento da função visual em lactentes ouvintes e surdos: importância para a aquisição da língua de sinais. Dist. Comun., v. 12, n. 2, p. 239-255, $2001 b$.

LIMA, M. C. M. P.; GAGLIARDO, H. G. R. G.; ARNAIS, M. A. O.; GONÇALVES, V. M. G. Observação do desenvolvimento de linguagem e funções auditiva e visual em lactentes. R. Saúde Públ., v. 38, n. 1, p. 106-12, 2004.

MACHADO, M. S.; OLIVEIRA, T. M. T.; CÓSEER, P. L. Triagem auditiva universal: projeto piloto no Hospital Universitário de Santa Maria (RS), Brasil.Pró-Fono R. Atual. Cient., v. 14, n. 2, p. 199-204, maio-ago. 2000.

MOTA, P. H.; NAKAMURA, H. Y.; PINTO, E. S. A questão do diagnóstico da surdez. Saúde R., v. 4, n. 2, p. 69-75, 2000.

MURRAY, J. S. Hearing screening in newborn. Current Opinion Otolaryngol. Head Neck Surg., v. 8, n. 6, p. 488507,2000 .

NAKAMURA, H. Y. Investigação do comportamento auditivo em recém-nascidos e lactentes. 1996. Dissertação (Mestrado em Ciências Médicas na àrea de Neurologia) Universidade Estadual de Campinas, Campinas.

NAKAMURA, H. Y. Uma Proposta de Avaliação Audiológica Comportamental em Lactentes utilizando o Sistema Sonar: Bandinha Digital. 2005. 213 f. Tese (Doutorado em Ciências Médicas na área de Neurologia) - Universidade Estadual de Campinas, Campinas.

NAKAMURA, H. Y.; LIMA, M. C. M. P.; GONÇALVES, V. M. G. Ambulatório de neurodiagnóstico da surdez: papel da equipe multidisciplinar. In: LACERDA, C. B. F.; NAKAMURA, H. Y.; LIMA, M. C. M. P.Fonoaudiologia: surdez a abordagem bilíngüe. São Paulo: Plexus, 2000.p. 103113.

NAKAMURA, H. Y.; ARAÚJO, F. C. R. S.; GONÇALVES, V. M. G.; SERVILHA, B. B.; ARAÚJO, A. M. L.; LIMA, M. C. M. P. Avaliação auditiva comportamental de lactentes de seis meses com o Sistema Sonar.Arq. Neuro-Psiquiat., v. 60, supl. 1, p. 154, 2002.
NORTHERN, J.; DOWNS, M. P. Avaliação Auditiva Comportamental. In: NORTHERN, J.; DOWNS, M. P. Audição na infância. 5. ed. Rio de Janeiro: Guanabara Koogan, 2005. p. 129-167.

NORTON, S. J.; GORGA, M. P.; WIDEN, J. E.; FOLSOM, R. C.; SININGER, Y.; CONE-WEASSON, B.; VOHR, B. R.; FLECTHER, K. A. Identification of neonatal hearing impairment: a multicenter investigation. Ear Hear., v. 21, n. 5, p. 348-356, 2000.

RUGGIERI-MARONE, M.; LICHTIG, I.; MARONE, S. A M. Recém-nascidos gerados por mães com alto risco gestacional: estudo das emissões otoacústicas produtos de distorção e do comportamento auditivo. R. Bras. Otorrinolaringol., v. 68, n. 2, p. 230-237, mar.-ab. 2002.

RUSSO, I. P. Overview of Audiology in Brazil: State of the Art. Audilogy, v. 39, n.4 p. 202-206, 2000.

SCHUBERT, S. H. Avaliação audiológica em crianças de 6 a 24 meses de idade utilizando a audiometria de reforço visual informatizada. 2000. Dissertação (Mestrado em xxx) - Pontifícia Universidade Católica, São Paulo.

TAUROZZI, N.; MONICI, M. M.; GAUDELLI, R.; TRUZZI, M.; SIVELLI, C.; PIZZI, P.; CARIA, A. R. Le otoemissioni acustiche nello screening uditivo neonatale: nostra esperienza. Otorrinolaringol., v. 53, n.4, p. 159-164, 2003.

YOSHINAGA-ITANO, C.; SEDEY, A. L.; COULTER, D. K.; MEHL, A. L. Language of early and later identified children with hearing loss. Pediatrics, v. 102, n. 5, p. 1161-1171, 1998.

WALCH, C.; ANDERHUBER, W.; KOLE, W.; BERGHOLD, A. Bilateral sensorineural hearing disorders in children: etiology of deafness and evolution of hearing testes. Inter. J. Pediatric Otorrinolaryngol., v. 53, n. 1, p. 31-38, 2000.

WEBER, B. A.; DIEFENDORF, A. Triagem auditiva neonatal. In: MUSIEK, F. E.; RINTELMANN, W. F. P erspectivas Atuais em Avaliação Auditiva. Barueri: Manole, 2001. cap. 11, p. 323-341.

WIDEN, J. E.; BULL, W. R.; FOLSON, R. C. Newborn hearing screeening: what for provides of early intervention Services. Infants Children, v. 16, n. 3, p. 249-257, 2003.

WIDEN, J. E.; O'GRADY, G. M. Using visual reinforcement audiometry in the assessment of hearing in infants. The Hear. J., v. 55, n. 5, p. 28-32, nov. 2002. 